\title{
PENGARUH METODE ACTIVE LEARNING TERHADAP PENINGKATAN MOTIVASI DAN KREATIVITAS BELAJAR PESERTA DIDIK DI ERA GLOBALISASI
}

\author{
Muhasim \\ STIT Palapa Nusantara Lombok-NTB \\ mhmsaidah@gmail.com
}

\begin{abstract}
Learning with conventional models with lecture methods is still widely practiced by the instructors, it cannot be said to be successful, the media used are less attractive, still use whiteboards and markers so students are less motivated, so that improvements are needed in accordance with the times. Active Learning method, can be used in changing the conventional way of learning. This method can have an effect on increasing the motivation and creativity, in order to be able to change the behavior of the face the globalization era that occurred along the progress of science and the development of technological information. Based on problems occurred, the researchers are interested in research the influence of active learning to increased motivation and creativity learning learners. Research methods qualitative, descriptive, namely through observation, using approach to data librarianship sourced from books and scientific material that is obtained at one of the Internet. Research results can become a reference in the learning process by either the teacher or learners, because it has given clarity how active learning influences the motivation and creativity of learners in the globalization era.
\end{abstract}

Keywords : Active Learning, Motivation, Novelty Learning, Globalization

\begin{abstract}
Abstrak : Pembelajaran dengan model konvensional dengan metode ceramah sampai sekarang masih banyak dipraktekkan oleh para pengajar, bukan tidak dapat dikatakan berhasil, Media yang digunakan kurang menarik, masih menggunakan papan tulis dan spidol sehingga siswa kurang termotivasi, sehingga diperlukan penyempurnaan sesuai dengan perkembangan zaman. Metode Active Learning, dapat digunakan merubah cara belajar konvensional. Metode ini dapat berpengaruh terhadap peningkatan motivasi dan kreatifitas, agar mampu merubah perilaku menghadapi era globalisasi yang terjadi seiring kemajuan Ilmu pengetahuan dan perkembangan teknologi informasi. Berdasarkan permasalahan yang terjadi, peneliti tertarik meneliti pengaruh active learning terhadap peningkatan motivasi dan kreativitas belajar peserta didik. Metode penelitian yaitu deskriptif kualitatif dengan melalui pendekatan pengamatan, munggunakan data kepustakaan yang bersumber dari buku-buku ilmiah dan materi yang diperolah dari Internet. Hasil penelitian dapat menjadi acuan dalam proses pembelajaran baik oleh pengajar maupun peserta didik, karena telah memberikan kejelasan bagaimana pengaruh active learning terhadap motivasi dan kreativitas peserta didik di era Globalisasi.
\end{abstract}

Kata Kunci : Active Learning, Motivasi, Kebaruan cara Belajar, Globalisasi 


\section{PENDAHULUAN}

Hukum alam telah menggiring kehidupan manusia seiring perubahan yang terus terjadi di era globalisasi dan tidak mampu dibendung oleh siapa pun. Kehidupan manusia pun, tidak pernah terlepas dari masalah, ibarat berlayar di lautan lepas, pasti sesekali menghadapi badai, angin dan arus, yang dapat saja mengancam keselamatan.

Penyelenggaraan pendidikan juga demikian, sebagai akibat dari metode yang selalu berubah. Metode pendidikan yang diterapkan secara konvensional, dengan cara yang sangat sederhana, terus mengalami perubahan dengan metode-metode lainnya, sehingga menyebabkan terjadi perbedaan dan dapat saja menimbulkan masalah. Metode yang diperkenalkan di era sekarang yang dapat meningkatkan motivasi dan kreativitas peserta didik yaitu metode active learning, yang berbeda dengan metode konvensional.

Metode active learning, tampaknya menjadi pilihan utama dalam praktik pendidikan di Indonesia. Gerakan perubahan ini menuntut para pendidik secara terus menerus menyesuaikan diri dengan perubahan yang terjadi. Dari sisi peserta didik, tingkat taraf seraf dalam ruang kelas hanya sekitar 40 persen dari waktu yang tersedia. ${ }^{1}$ Sementara peneliti lain menyebutkan bahwa dalam sepuluh menit pertama perhatian siswa dapat mencapai $70 \%$, dan berkurang sampai menjadi $20 \%$ pada waktu 20 menit terakhir. ${ }^{2}$

Kondisi tersebut di atas merupakan kondisi umum yang sering terjadi di lingkungan sekolah. Hal tersebut memang perlu menjadi perhatian pendidik dan pihak sekolah. Masalah semakin menurunnya tingkat taraf seraf peserta didik, yang perlu dicermati faktor-faktor penyebab, apakah pengaruh lingkungan sekolah dan atau lingkungan tempat tinggal, atau asupan gizi di lingkungan keluarga.

Kaitannya dengan asupan gizi, kondisi ekonomi keluarga, di Lombok Timur sebagian besar menekuni lapangan pekerjaan di sektor pertanian, dengan tingkat penghasilan yang rendah, sehingga pendudukan Lombok Timur masih tergolong miskin. Kondisi ekonomi keluarga yang tergolong miskin, bukan saja pengaruhnya

${ }^{1}$. Polio ( 1984 ), https://media154.wordpress.com/artikel-internet-desain-dan-web-3/strategipembelajaran-active-learning/ 2 . McKeachie (1986), https://media154.wordpress.com/artikel-internet-desain-dan-web-3/strategipembelajaran-active-learning/ 
terhadap menurunnya tingkat araf seraf, tetapi juga faktor penyebab banyak yang putus sekolah dan sebagian lagi tidak mampu melanjutkan pendidikannya ke jenjang yang lebih tinggi.

Faktor-faktor penyebab, secara umum adalah penggunaan metode pembelajaran, masih menimbulkan masalah. Itulah yang menarik minat peneliti mengambil judul kajian, benarkah Metode Active Learning berpengaruh terhadap peningkatan motivasi dan kreativitas belajar peserta didik.

\section{KAJIAN PUSTAKA}

\section{ACTIVE LEARNING}

Active learning (pembelajaran aktif) merupakan sebuah kesatuan sumber kumpulan model pembelajaran yang komprehensif meliputi berbagai cara untuk membuat siswa aktif. ${ }^{3}$ Active learning sebuah model pembelajaran yang menekankan pada aktifitas dan partisipasi aktif mahasiswa dari segi intelektual dan emosional secara optimal melalui aktivitas belajar di dalam tim dan antar tim (team teaching) untuk memperoleh penguasaan/pemahaman materi secara lebih bermakna. ${ }^{4}$

Pembelajaran aktif (active learning) adalah suatu pembelajaran yang mengajak peserta didik untuk belajar secara aktif. Ketika peserta didik belajar dengan aktif, berarti mereka yang mendominasi aktifitas pembelajaran. Mereka secara aktif menggunakan otak mereka baik untuk menemukan ide pokok dari materi pelajaran, memecahkan persoalan atau mengaplikasikan apa yang baru mereka pelajari ke dalam suatu persoalan yang ada dalam kehidupan nyata. ${ }^{5}$

Menurut Bonwell pembelajaran aktif memiliki Karakteristik sebagai berikut: 1. Penekanan proses pembelajaran bukan pada penyampaian informasi oleh pengajar melainkan pada pengembangan keterampilan pemikiran analitis dan kritis terhadap topik atau permasalahan yang dibahas, 2. Mahasiswa tidak hanya mendengarkan kuliah secara pasif tetapi mengerjakan sesuatu yang berkaitan dengan materi kuliah, 3 .

\footnotetext{
${ }^{3}$ Silberman ( 2009:xxii), https://media154.wordpress.com/artikel-internet-desain-dan-web3/strategi- pembelajaran-active-learning/

${ }^{4}$ Ali Muhtadi, Model Pembelajaran “Active Learning” dengan Metode Kelompok untuk Meningkatkan Kualitas Proses Pembelajaran di Perguruan Tinggi, 2019 : 4.

5. Zaini, Skripsi dengan judul :Implementasi Metode Active Learning Dalam Pembelajaran Pendidikan Agama Islam Kelas V Di Sd Islam Al-Azhar 28 Solobaru, tahun 2018 : 8
} 
Penekanan pada eksplorasi nilai-nilai dan sikap-sikap berkenaan dengan materi kuliah, 4. Mahasiswa lebih banyak dituntut untuk berpikir kritis, menganalisa dan melakukan evaluasi, 5. Umpan-balik yang lebih cepat akan terjadi pada proses pembelajaran. $^{6}$

Uraian -uraian di atas memberikan gambaran, bahwa perubahan metode pembelajaran dimaksudkan untuk meningkatkan prestasi peserta didik. Active learning sudah merupakan kombinasi dari beberapa metode. Selain dari penggunaan metode juga dapat berpengaruh terhadap partisipasi yaitu lingkungan belajar. Faktor metode dan lingkungan belajar baik disadari atau tidak memberikan pengaruh terhadap pembelajaran aktif peserta didik. Jika faktor menyenangkan, memberikan rasa aman, nyaman, potensi peserta didik metode belajar dapat berkembang secara optimal dan proses pembelajaran akan berjalan lancar.

Active learning, pembelajaran terfokus pada peserta didik, karena merekalah yang belajar, ia datang mencari ilmu, bukan menuntut ilmu, sehingga peserta didik harus aktif belajar dengan berbagai upaya, bukan lagi bagaimana pengajar mengajar dengan baik, tetapi bagaimana peserta didik bisa belajar dengan baik. Pengajar sebagai fasilitator dan motivator. Active learning berusaha membangkitkan motivasi dan kreativitas peserta didik, dengan berbagai cara termasuk memanfaatkan teknologi informasi, sebagai media pembelajaran. Motivasi dan kreativitas, sebagai motor penggerak menyeimbangkan antara kemauan dan kemampuan, karena bisa saja seseorang punya kemauan, tetapi tidak punya kemampuan atau tidak tahu caranya, itulah tugas pengajar untuk memediasi serta memanfaatkan kerja sama dalam kelompok.

Kerja sama, disiplin waktu, penyelesaian tugas-tugas individu maupun kelompok, harus diselesaikan dengan ikhlas hati, tidak merasa dipaksa, dengan demikian akan tercipta suasana belajar yang kondusif, tenang, nyaman dan menyenangkan. Komunikasi terjalin serta terbina dengan baik dan lancar antara peserta didik dan pendidik, untuk dapat memecahkan masalah dengan cepat dan baik.

Menurut seorang ahli, belajar hanya bisa dipahami jika terjadi penerapan

${ }^{6}$. Mukhlison Effendi, Integrasi Pembelajaran Active Learning dan Internet-Based Learning dalam Meningkatkan Keaktifan dan Kreativitas Belajar Nadwa | Jurnal Pendidikan Islam Vol. 7, Nomor 2, Oktober 2013: 288, 
strategi pembelajaran aktif adalah salah satu strategi yang digunakan untuk mengoptimalkan proses pembelajaran, yang senantiasa memposisikan guru sebagai orang yang menciptakan suasana belajar yang kondusif atau sebagai fasilitator dalam belajar, sementara peserta didik harus aktif, inovatif dan lingkungan dimanfaatkan sebagai sumber belajar yang kreatif, efektif, dan menarik ${ }^{7}$

Dari beberapa pengertian tentang active learning (pembelajaran aktif) sebagaimana diuraikan di atas, bukan saja sekedar mengganti metode konvensional, tetapi bagaimana membangkitkan kemandirian peserta didik dengan meningkatkan motivasi dan kreativitas dalam belajar. Dan yang tidak kalah pentingnya, mampu memanfaatkan peluang kemudahan-kemudahan, membuat kepraktisan dalam berperilaku, memanfaatkan kemajuan teknologi informasi, karena sikap dan perilaku, menciptakan motivasi dan kreativitas menghadapi zaman globalisasi yang tidak bisa dibendung.

\section{MOTIVASI}

Motivasi lahir sejak manusia dilahirkan ke muka bumi ini, sudah tumbuh dalam dirinya motivasi menginginkan sesuatu, mesti sifatnya masih alami, tanpa pertimbangan pikiran, tetapi sudah mengandung nilai walaupun masih untuk kepentingan sendiri. Berkembangnya ilmu pengetahuan, para ilmuan mulai mempelajari secara ilmiah, melalui penelitian-penelitian dengan latar belakang ilmu yang berbeda. Lahirlah pengertian motivasi dari berbagai pandangan dengan definisi yang berbeda, walaupun mengandung makna serta tujuan yang sama.

Lyman Porter dan EE.Lowler, motivasi di tempat pada nilai yang dipergunakan orang untuk sesuatu tujuan seperti juga pandangan seseorang terhadap kesamaan dalam tempat kerja atau keadilan sebagai faktor-faktor yang mempengaruhi kelakuan kerja orang tersebut. ${ }^{8} \quad$ Motivasi adalah dorongan yang timbul pada diri seseorang sadar atau tidak sadar untuk melakukan suatu tindakan dengan tujuan

7. Nur Asiah, menurut Uno, Jurnal Pendidikan dan Pembelajaran Dasar Volume 4 Nomor 1 Juni 2017:22.

8. Robert L. Mathis dan John H.Jackson, Manajemen Sumber Daya Manusia, Salemba Empat, Jakarta, 91. 
tertentu. ${ }^{9}$ Teori motivasi lain mengemukakan bahwa manusia pada hakikatnya mempunyai kemampuan untuk berprestasi di atas kemampuan orang lain. ${ }^{10}$ Motivasi merupakan salah satu komponen penting dalam meraih keberhasilan suatu proses kerja, karena memuat unsur pendorong bagi seseorang untuk melakukan pekerjaan sendiri maupun kelompok. ${ }^{11}$

Ahli lain mendefinisikan motivasi sebagai keseluruhan proses pemberian motif bekerja kepada para bawahan sedemikian rupa sehingga mereka mau bekerja dengan ikhlas demi tercapainya tujuan organisasi dengan efisien dan ekonomis. ${ }^{12}$ Slameto berpendapat bahwa lingkungan belajar siswa yang berpengaruh terhadap prestasi belajar terdiri dari Lingkungan Keluarga, Lingkungan Sekolah, dan Lingkungan Masyarakat. ${ }^{13}$

Motivasi itu mengandung nilai moral, sehingga yang bicarakan di sini adalah motivasi yang memberikan manfaat kebaikan bagi diri sendiri dan kemaslahatan bagi masyarakat. Definisi-definisi yang diuraikan di atas, menjadi bahan untuk menafsirkan secara umum apa yang terkandung di dalam kata-kata motivasi. Banyak ahli banyak pendapat, semakin banyak ahli yang memberikan definisi tentang motivasi semakin banyak definisi yang bisa didapat, bahkan lebih banyak dari orang yang memberikan definisi tersebut. Definisi tersebut berkisar antara manusia, perilaku dan kebutuhannya. Manusia itu sifatnya egois, ia bersedia berbuat sesuatu yang diminta, bila mendapat imbalan, karena memang ia harus memenuhi kebutuhan keluarganya. Semakin tinggi profesionalismenya, semakin lama ia bekerja, semakin besar upah yang dimintanya.

Motivasi dari seseorang akan berbeda nilainya satu sama lainnya, tergantung negosiasi antara seseorang dengan yang meminta jasa, seorang buruh pabrik akan beda motivasinya dengan seorang karyawan Bank, seorang petani beda motivasinya

9 . Departemen Pendidikan dan Kebudayaan, KBBI, Penerbit Balai Pustaka, Jakarta , tahun 1990:593.

10 . Miftah Thoha, Perilaku Organisasi, Penerbit PT Raja Grafindo Persada, Jakarta, tahun 1999:206.

11. Triguno, DIPL EC.,LLL, Drs.Budaya Kerja, Diterbitkan PT Golden Trayon Press, Jakarta tahun 2003:125.

12. S.P.Siagian, MPA, Dr, Filsafat Adminstrsi, Penerbit PT Gunung Agung, Jakarta, tahun 1980: 129

13. Achmad Muslih, Skripsi, Pengaruh Lingkungan Belajar, Kebiasaan Belajar Dan Motivasi

Belajar Terhadap Hasil Belajar, Fakultas Teknik Universitas Negeri Yogyakarta, Tahun 2014:14. 
dengan seorang prajurit, peserta didik motivasinya mengharapkan prestasi belajar yang baik. Peserta didik pada tingkat yang berbeda tentu juga akan beda nilai motivasi, namun intinya seseorang termotivasi untuk melakukan sesuatu yang memberikan manfaat imbalan materi atau jasa.

Motivasi memberikan pembeda seseorang dengan orang lainnya, beda karakter, beda kemauan, beda juga kemampuan, walaupun mereka satu alumni, samasama berpendidikan S-1. Tuntutan hidup setiap orang berbeda, tergantung kebutuhan, dan emosionalnya, harapan tidak selama sesuai dengan kenyataan, karena ada yang acuh dan ada yang suka bekerja keras. Setiap orang punya kemauan, tetapi kemampuan tidak cukup, tidak dapat berbuat apa-apa, sebaliknya kemampuan ada tetapi kemauan gak ada, ya , jadi penganggur. Motivasi menurut tingkat kebutuhan, sebagaimana dikemukakan Abraham H. Maslow, menggolongkan kebutuhan manusia itu menjadi lima tingkat kebutuhan, 1. Kebutuhan bersifat fisik ( sandang pangan, pangan, papan) 2. Kebutuhan keamanan yaitu keamanan jiwa dan harta, 3. Kebutuhan-kebutuhan sosial yaitu kebutuhan akan pergaulan dan dihormati, 4. Kebutuhan yaitu tidak senang menghadapi kegagalan dan merasa senang jika mendapatkan kemajuan, 5. Kebutuhan akan perasaan yaitu diajak ikut berpartisipasi, diberikan kesempatan untuk memberikan saran-saran, ide-ide, pendapat. ${ }^{14}$ Secara spesifik dalam metode pembelajaran active learning tidak bisa diambil secara urutan kebutuhan, karena itu bisa dipenuhi oleh keluarganya. Dalam hal pembelajaran lebih tepat dilihat dari konteks yaitu metode pembelajaran antara lain diikutkan berpartisipasi dalam dalam proses belajar, diberikan kesempatan memberikan ide-ide, memberikan saran-saran untuk memperlancar proses pembelajaran, dan itu memang menjadi roh metode active learning.

Peneliti menggolongkan motivasi itu minimal dua macam, motivasi untuk kejahatan, dan motivasi untuk kemaslahatan, Motivasi yang dibahas dalam penelitian ini, adalah motivasi yang mendatangkan kemaslahatan bagi peserta didik dan bagi banyak orang.

${ }^{14}$. S.P. Siagian, op.cit : 131. 


\section{KREATIVITAS}

Kreativitas merupakan bawaan seseorang sejak lahir, walaupun hanya mampu disampaikan dengan simbol-simbol, gerakan-gerakan, tetapi dapat dimengerti kenapa mereka melakukan gerakan itu. Dari manusia pertama ada di bumi ini, Adam dan Hawa, ia menemukan hutan belantara, tidak ada tanaman pertanian sebagai sumber makanan seperti yang ada sekarang. Ia memiliki motivasi untuk makan, dan ia menggerakkan kreativitasnya untuk memenuhi kebutuhannya, dengan cara memburu hewan dan memilih buah tanaman yang enak dimakan, sampai sekarang anak cucunya menikmati kreativitasnya Nabi Ada. Zaman Purba yang sumber daya manusianya masih ortodok, ia sudah menunjukkah tingginya kreativitas mereka. Alat-alat pertanian sampai alat-alat dapur dibuat dari batu dan kayu. Menyalakan api, dari hentakan batu atau dari kayu dengan digosok-gosokkan, walaupun zaman kuno tersebut, belum mengenal teori ilmiah motivasi dan kreativitas.

Zaman globalisasi yang disebut modern selain memberikan kemudahankemudahan, fenomena kehidupan bermasyarakat syarat tantangan dari berbagai segi, pengaruh negatif teknologi informasi, perkembangan ekonomi yang tidak seimbang, perubahan sosial cenderung hidup individualistis dan pertukaran nilai-nilai budaya yang jauh berbeda dengan nilai budaya setempat. Penduduknya sangat padat, lapangan pekerjaan terbatas, persaingan peluang lapangan sangat ketat. Banyaknya tantangan tersebut kesiapan untuk menghadapinya adalah melalui pendidikan. Berbicara pendidikan selain masalah kurikulum juga metode pembelajaran harus terus disempurnakan, dari metode konvensional, dengan metode memungkinkan dapat mewujudkan tujuan, sekarang dikenal metode active learning.

Zaman modern sekarang, sudah berkembang ilmu pengetahuan, dari para ahli lahir teori-teori kreativitas dengan berbagai macam definisi sesuai dengan latar belakang ilmu yang dimiliki. Kreativitas adalah penyatuan pengetahuan dari berbagai bidang pengalaman yang berlainan untuk menghasilkan ide-ide yang baru dan lebih baik. ${ }^{15}$ Lebih lanjut diungkapkan bahwa kita semua pada dasarnya dapat menciptakan pendekatan-pendekatan baru guna menyelesaikan berbagai masalah, yang muncul dalam menjalani kehidupan sehari-hari.

15 . Michael A.West, Mengembangkan Kreativitas Dalam Organisasi, Penerbit Kanisius, Yogyakarta, tahun 2000:14. 
Kreativitas atau crativity adalah sebuah istilah untuk menunjukkan suatu daya di alam semesta yang memungkinkan hadirnya entitas aktual yang baru berdasarkan entitas aktual-entitas aktual yang lain. ${ }^{16}$

Kreativitas seluruh proses di mana ide dicetuskan, dikembangkan, dan diubah menjadi nilai. Kreativitas mengandung tujuan yang umumnya ingin dicapai orang dengan inovasi dan semangat wirausaha. ${ }^{17}$ Lebih lanjut dijelaskan, kreativitas mempunyai dua arti yaitu seni melahirkan ide2 baru dan disiplin dalam membentuk dan mengembangkan ide2 tersebut menjadi nilai yang nyata. Istilah lain kreatifitas adalah kemampuan untuk mencipta atau proses timbulnya ide-ide. ${ }^{18}$

Utami Munandar menjelaskan Pengertian kreativitas dengan mengemukakan beberapa perumusan yang merupakan kesimpulan para ahli mengenai kreativitas. Pertama, kreativitas adalah kemampuan untuk membuat kombinasi baru berdasarkan data, informasi, atau unsur-unsur yang ada. Kedua, kreativitas (berpikir kreatif atau berpikir divergen) adalah kemampuan berdasarkan data atau informasi yang tersedia, menemukan banyak kemungkinan jawaban terhadap suatu masalah, di mana penekanannya adalah pada kuantitas, ketepatgunaan, dan keragaman jawaban. Ketiga secara operasional kreativitas dapat dirumuskan sebagai kemampuan yang mencerminkan kelancaran, keluwesan (fleksibilitas), dan orisinalitas dalam berpikir, serta kemampuan untuk mengelaborasi (mengembangkan, memperkaya, merinci) suatu gagasan. ${ }^{19}$

Suatu definisi yang lebih ilmiah menyatakan bahwa kreativitas adalah suatu pertimbangan subjektif dan berkonteks spesifik mengenai kebaruan dan nilai suatu hasil dari perilaku individual dan kolektif. ${ }^{20}$

Belajar aktif menurut Nana Sudjana di antaranya: 1. Turut serta dalam melaksanakan tugas belajarnya 2. Terlibat dalam pemecahan masalah 3. Bertanya kepada peserta didik lain atau kepada guru apabila tidak memahami persoalan yang dihadapinya 4. Berusaha mencari berbagai informasi yang diperlukan untuk pemecahan masalah 5. Melaksanakan diskusi kelompok sesuai petunjuk guru 6.

16 . Alfred North Whitehead, https://id.wikipedia.org/wiki/Kreativitas(Filsafat_Proses)( Diakses 17 Mei 2019 ).

17. Triguno, DIPL EC.,LLL, op.cit : 125.

18. KBBI, Op, cit, 1990:465.

19 . Mukhlison Effendi, of,cit, $2013: 295$.

20 . Michael A. West, op.cit: 14 
Menilai kemampuan dirinya dan hasil-hasil yang diperolehnya 7. Melatih diri dalam memecahkan soal atau masalah sejenis 8. Kesempatan menggunakan atau menerapkan apa yang diperolehnya dalam menyelesaikan tugas atau persoalan yang dihadapi. ${ }^{21}$.

Kretivitas, merupakan hasil perkembangan pemikiran seseorang dari hasil pengatan aktivitas, fenomena yang terjadi dalam proses kehidupan masyarakat, baik mengambarkan kemajuan maupun menimbulkan masalah. Muncul ide-ide, pemikiran inovatif, istilah teroritis diatas, menghasilkan entitas kebaruan atau merekayasa ulang entitas-entitas yang sudah ada sebelumnya, baik yang bersifat fisik, fsikis atau non fisik, dan menghasilkan karya baru, yang mendatangkan kemaslahatan bagi kehidupan masyarakat.

\section{GLOBALISASI}

David Held dan Anthony Mc. Crew, kata globalisasi dapat diartikan dalam pemaknaan yang beragam seperti kedekatan jarak, ruangan, waktu yang menyempit, pengaruh cepat, dan dunia yang menyempit. ${ }^{22}$ Lebih lanjut dijelaskan David, kata globalisasi secara sederhana dapat diartikan sebagai melenyapkan dinding dan jarak antara satu bangsa dengan bangsa lain, antara satu kebudayaan dengan kebudayaan lain. Dengan kata lain globalisasi ialah merubah dunia menjadi perkampungan dunia.

Begitu juga dalam aspek pendidikan, globalisasi telah berpengaruh terhadap penyelenggaraan pendidikan, baik terhadap tujuan, proses, hubungan peserta didik dan pendidik, etika, metode ataupun yang lainnya. ${ }^{23}$ Dalam hal ini metode active learning sangat cocok diterapkan, untuk memasuki era globalisasi, selain peserta didik tidak saja dapat menamatkan pendidikannya, tetapi mereka mempunyai kompetensi, mampu merubah sikap dan perilaku menghadapi dampak globalisasi.

Ahli lain memberikan pengertian globalisasi adalah intensifikasi hubungan sosial secara mendunia sehingga menghubungkan antara peristiwa di satu lokasi

\footnotetext{
21 . Mukhlison Effendi, op. cit: 294

22 . Nur Latifah, Pendidikan Islam di Era Globalisasi, Palapa: Jurnal Studi Keislaman dan Ilmu Pendidikan Volume 5, Nomor 1, Mei 2017: 202.

23 . Ibit, Nur Latifah, halaman 202.
} 
dengan lokasi lainnya serta menyebabkan perubahan pada keduanya. ${ }^{24}$ Dari makna definisi tersebut dapat dipahami bahwa dunia yang demikian luas, dengan kemajuan teknologi informasi, terasa dunia ini seolah-olah semakin sempit, pertukaran informasi budaya, gaya hidup, dan lainya berpengaruh kepada penduduk kedua sumber asal informasi, yang kadang-kadang nilai-nilai diantara keduanya tidak sesuai dengan nilai budaya setempat.

Sifatnya yang sangat luas itu, tidak menutup kemungkinan faktor -faktor yang mempengaruhi cenderung lebih besar dari Negara yang lebih maju, karena lebih dahulu merasakan kamajuan. Sementara yang dipengaruhi, Negara-negara biasa disebut sedang berkembang, pengaruhnya meliputi seluruh aspek kehidupan manusia, ekonomi, sosial, politik dan budaya. Sektor ekonomi perkembangan perdagangan sudah mencapai tahap perdagangan bebas, MEA( Masyarakat Ekonomi Asia dan MEE ( Masyarakat Ekonomi Eropa ). Produk bangsa lain Madein Cina seperti HP sudah menguasai Indonesia, tenaga kerja cita banyak di Indonesia. Di sektor sosial, bahasa telah menjadi alat pemersatu antar bangsa, perkawinan antar warga Negara, suku, pertukaran pelajar dan mahasiswa sudah merupakan kegiatan biasa. Di sektor politik, demokrasi sudah menjadi alat untuk mengintervensi bangsa lain, HAM dan sebagainya. Pertukaran budaya antar bangsa, sudah berasimilasi dengan membawa nilai budaya masing-masing, walaupun tidak sesuai dengan nilai-nilai budaya setempat.

Faktor-faktor diatas telah memperkaya pengetahuan tentang kata globalisasi, pengaruh positif dan negatifnya, sudah sulit dibendung, sebab muncul dengan tiba, ketika kita membuka atau On kan HP, belum lagi dari TV nasional yang sudah menampilkan berbagai ragam budaya dan gaya hidup. Berbagai model pakaian dan cara berpakaian, yang kadang-kadang tidak sesuai kebiasaan dan adat istiadat nilai budaya lokal. Semua persoalan yang muncul dari sisi positifnya harus dipandang sebagai peluang untuk maju, dan pendidikan salah satu benteng mempersiapkan sikap dan perilaku masyarakat untuk menangkal pengaruh negatifnya. Oleh karena pendidikan harus dikelola dengan baik dan dijalankan dengan metode yang tepat terhadap peserta didik sebagai bagian kader penerus bangsa.

${ }^{24}$. Anthony Giddens, Globalisasi, https://id.wikipedia.org/wiki/Globalisasi ( diakses 20 Mei 2019 ) . 


\section{PEMBAHASAN}

\section{Active Learning Terhadap Motivasi Belajar.}

Motivasi merupakan unsur penting dalam kehidupan seseorang, tanpa motivasi tidak mungkin bisa berinovasi dan berkreasi. Motivasi mengandung nilainilai moral, yang menurut pandangan masing-masing orang, tentu berbeda, tergantung dari sudut mana memandangnya, dan seseorang mau melakukan tindakan tertentu. Artinya faktor nilai mempengaruhi motivasi seseorang berperilaku, namun secara umum nilai saja tidak cukup hanya dengan niat, tanpa perilaku, maka untuk merespon motivasi perlu ada metode-metode tertentu.

Metode merupakan cara yang harus dilakukan, misalkan seseorang berkeinginan membuat sebuah pakaian, mesti ada pola yang didesain terlebih dahulu, model seperti apa pakaian yang akan dibuat. Katakanlah metode active learning, merupakan pola dari desain sebuah pembelajaran, seperti apa pola yang harus ditempuh, sudah tergambar dalam landasan teori karakteristiknya sebagaimana dikemukakan Bonwell. Peserta didik mampu pengembangan pemikiran yang memperkuat daya analitis dan kritisnya, baik dalam berdiskusi maupun pada saat evaluasi. Menyangkut masalah eksplorasi nilai-nilai dan sikap-sikap, maka pengajar harus menjadi contoh penerapan akhlak mulia. Jika karakteristik tersebut, berproses secara normal, akan berpengaruh terhadap perubahan perilaku positif, sehingga menjadi menjadi umpan balik, serta evaluasi bagi penerapan metode untuk menyempurnakan berikutnya.

Sesorang tergerak untuk beraktifitas, berperilaku, ada motivasi tertentu, dengan kata lain mustahil seseorang mau kerja tanpa ada tujuan atau kehendak akan diwujudkan. Menggunakan metode active learning, peserta didik dilatih untuk membangkitkan motivasinya. Metode active learning peserta didik, dididik mengolah materi pelajaran menggunakan kemampuan pikiran mereka secara mandiri, mengembangkan ide mencari kata kunci dari materi pelajaran, agar lebih mudah memahami serta memecahkan kesulitan dalam belajar, dan mampu mengaplikasikannya dalam kehidupan sehari-hari. Aplikasi teori dalam belajar ditunjang oleh semangat kemandirian serta percaya diri, bahwa mereka sudah memiliki bekal ilmu pengetahuan, sebagai lampu penerang, di malam gelap, menjadi 
kompas dalam menentukan arah perjalanan mereka dalam kehidupan bermasyarakat yang jauh lebih kompleks di era globalisasi ini. Pengaruh dari pemahaman kritis dan analisis penggunaan metode active learning, dapat menjadi pemicu meningkatnya motivasi belajar serta dapat meningkatkan kepekaan peserta didik memotivasi dirinya jika ingin ikut maju dan menikmati kemajuan.

Menjalankan sesuatu metode pembelajaran membangkitkan motivasi untuk berubah ke arah yang lebih baik, memanfaatkan peluang yang dapat memberikan manfaat dalam belajar, menempa diri dalam belajar untuk lebih dewasa, berkualitas serta sukses dalam menempuh pendidikan. Setiap orang memiliki harapan ingin sukses, ingin bahagia, ingin sejahtera dalam hidupnya, tetapi harapan itu hanya mengotori kertas putih dengan tulisan tanpa makna, jika tidak berusaha dengan serius, santai dan sukses. Tentu 3.S itu bisa diwujudkan melalui belajar yang serius, mengikuti metode yang baik. Terhadap adanya kegagalan selama ini dalam pengelolaan pendidikan, tidak pernah ada kata bersalah terhadap lambannya perkembangan kualitas pendidikan selama ini. Kesalahan masa lalu menjadi bahan renungan, dan setiap waktu menjadi pikiran bersama, bagaimana mencetak warga Negara yang cerdas, jujur, beriman dan berakhlak mulia.

Itulah manfaat penerapan metode pembelajaran yang berkualitas, dengan memo besar motivasi harus ditingkatkan, agar sikap dan perilaku, tidak terkurung menyesalkan kegagalan masa lalu, untuk apa memutar jarum jam kezamam Ortodok, kita sudah berada di era globalisasi. Kemajuan ilmu pengetahuan dan teknologi informasi, memberikan peluang dan kemudahan-kemudahan dalam kehidupan bermasyarakat, seseorang yang mempunyai motivasi, zaman ini zamannya seseorang memotivasi dirinya. Perubahan tanpa motivasi ibarat kendaraan tanpa ada kunci kontak, ibarat kipas angin, tanpa berputar, artinya tidak bisa mendatang manfaat, tidak menyenangkan. Seseorang harus dapat memanfaatkan ilmu pengetahuannya, ikut maju bersama, jangan seperti kehilangan konpas kehidupan, ketika dipersimpangan jalan dan tempat yang ramai, kebingungan tanpa tahu arah, kuncinya ilmu pengetahuan, keterampilan, maksudnya selain memiliki kemampuan, juga kemauan atau motivasi.

Ilmu pengetahuan yang baik yang bermanfat bagi kemaslahatan masyarakat, dan pasti mendatangkan manfaat bagi diri sendiri. Pengembangan Ilmu 
pengetahuan yang berhasil, pastilah menggunakan metode pembelajaran yang berkualitas, dan berdampak positif bagi peningkatan motivasi peserta didik belajar. Merncermati analisa di atas, metode active learning, salah satu metode yang tepat, memiliki karaktristik teruji, mengandung kebaikan-kebaikan yang dapat memberikan motivasi belajar peserta didik. Banyak peserta didik yang memiliki kemampuan IQ tinggi, tetapi metode pembelajaran kurang tepat dan membosankan, tidak membangkitkan motivasi belajar.

Selain metode, lingkungan juga berpengaruh bagi motivasi belajar, apakah kingkungan keluarga kurang mendukung, salah teman bergaul, lingkungan sosial kurang kondusip, dapat mematikan motivasi belajar. Lingkungan sekolah harus diciptakan agar memberikan rasa nyaman, aman, menyenangkan, agar tumbuk motivasi belajar. Peran Sekolah harus mampu mendesian metode pembelajaran, memilih metode pembelajaran, menciptakan lingkungan yang membangkitkan motivasi peserta didik.

Peserta didik memiliki karakter berbeda, perilaku yang unik, mereka memiliki kekuatan, kelemahan, minat, dan perhatian yang berbeda-beda, latar belakang keluarga, latar belakang sosial ekonomi, dan lingkungan, membuat peserta pendidik berbeda dalam aktivitas, kreativitas, intelegensi, dan kompetensinya. ${ }^{25}$ Teori di atas dapat menjadi panduan, dalam rangka penggunaan metode pembelajaran, karena tingkat kekuatan dan kelemahan motivasi peserta didik pasti berbeda, sebagai akibat dari berbagai macam latar belakang peserta didik itu sendiri, baik internal maupun eksternal. Penggunaan metode active learning yang terfokus pada peserta didik, dapat membantu memecahkan masalah yang dihadapi peserta didik, khusunya masalah motivasi belajar. Tentu pengajar tidak mungkin memahami munculnya gangguan tersebut, oleh karenanya untuk akar masalah, pendidik harus mampu belajar sambil bergurau, lain katanya pengajar harus membina keakraban bersama peserta didik, karena bisa jadi masalah itu muncul dari sebab berbeda. Artinya tidak dengan marah-marah, mengancam, menghukum dengan cara yang mendidik, tanpa kekerasan, mendidik dengan lemah lembut, untuk menggairahkan kembali motivasi belajar peserta didik.

${ }^{25}$. Dadang Suhardi, dkk, Manajemen Pendidikan, penerbit Alfabeta, Bandung, tahun 2012: 205. 


\section{Active Learning Terhadap Kreativitas}

Kreativitas merupakan jiwa kehidupan setiap orang, dibawa sejak lahir, walaupun baru mampu disampaikan lewat simbol-simbol, atau gerakan tertentu, tetapi mampu dipahami oleh seorang ibu. Nabi Adam AS, dan istrinya Situ Hawa, manusia pertama penghuni bumi, hidup dalam hutan belantara, yang belum ada lahan pertanian atau lahan perkebunan, sebagai sumber mata pencaharian saat itu, mampu hidup karena memiliki kreativitas. Bisa hidup dengan memburu hewan-hewan, memilih buah-buahan mana yang enak dan mana yang beracun, sampai memeliki keturunan, Qabil dan Khabir, adik Qabil dan adik Khabir. Sejak itulah turun temurun sampai manusia terakhir nantinya, dididik untuk kreatif.

Zaman Purba yang dikenal dengan zaman batu, mereka mampu membuat peralatan pertanian sampai perlengkapan dapur, terbuat dari batu dan kayu. Menyalakan apipun, pada saat itu belum ada korek jenis apapun, tetapi mereka menyalakan api, dengan peraduan batu dengan batu, kayu dengan menggosokkannya dikayu lain, muncul api, sebagai bukti mereka memiliki kreativitas.

Berkembang ilmu pengetahuan dimotori Negara-negara di Eropa Barat, sampai Negara sedang berkembang seperti Indonesia, ilmu pengetahuan. Mulai berkembang kajian-kajian secara imiah istilah kreativitas, dari para pakar, dengan berbagai macam istilah atau definisi yang mungkin lebih banyak dari orang melahirkannya.

Definisi-definisi yang dikemukan para ahli, memberikan pemahaman bahwa kreativitas merupakan kekuatan daya nalar manusia, proses berpikir seseorang, mengapa seseorang berperilau, karena mereka mau berubah dan berkembang kearah yang memberikan keuntungan bagi dairinya dan kemaslahatan bagi masyarakat. Menurut Gowan ( 1981), semua system otak manusia terlibat pada tingkat tinggi, pada saat terjadi kreatifitas. ${ }^{26}$ Dari definisi tersebut, dijelaskan beda kreatifitas personal dan cultural. Semua orang memiliki dasar kreativitas, dan yang bersangkut paut dengan kepentingan umum disebut kreativitas kebudayaan. Dasar itu dapat ditarik pemahaman, setiap manusia sudah memiliki kreativitas, sehingga tidak ada

${ }^{26}$. Conny R. Semiawan, Prof.DR, dkk, Dimensi Kreatif Dalam Filsafat Ilmu, penerbit PT. Remaja Rosdakarya,Bandung, tahun 1999:61. 
alasan seorang tidak akan berubah, perubahan besar kecilnya tergantung pada nilai moral yang dimilikinya. Seseorang yang mampu berubah kearah menyenangkan adalah orang kreatif, tanpa kreativitas ia akan mengalami kenyataan kehidupan yang buruk.

Kreativitas itu merupakan bawaan seseorang sejak lahir, namun perlu juga dibina agar bisa menyesuaikan diri dengan perubahan global yang terjadi. Dibidang pendidikan, pembinaan melalui proses yang cukup panjang, minimal sesuai dengan janjang pendidikan yang diperoleh. Secara logika, metode active learning, merupakan metode kebaruan, sehingga diasumsikan dapat memberikan pengaruh terhadap kreativitas belajar peserta didik. Dari unsur-unsur teori Michael A.West, Alfred, Tigunno dan lainnya, memberikan pemahaman bahwa kreativitas selain disebabkan kekuatan individual untuk menghasilkan ide-ide baru, juga ada motivasi eksternal dari daya alam semesta yang memungkinkan lahirnya entitas actual yang baru, dan inovasi untuk menciptakan nilai kreativitas yang nyata.

Belajar aktif pendapat para ahi, adalah suatu pembelajaran yang menggambarkan keaktifan, kearifan dan partisipasi siswanya, dalam proses pembelajaran baik bekerja mandiri ataupun dengan bimbingan pengajar di sekolah. Proses pembelajaran yang demikian akan membangkitkan kreatifitas peserta didik. Kreativitas bukan harus menghasilkan suatu karya baru, ide, perspektif baru seratus persen, tetapi dapat merupakan kombinasi-kombinasi ide-ide dari karya yang sudah ada, pembentukan pola baru atau korelasi baru yang berbeda yang yang pernah ada. Hal ini tergantung kreativitas seseorang untuk menghasilkan entitas dengan lain ujud, dari entitas yang mendahuluinya. Semakin banyak informasi, pengetahuan, pengalaman seseorang, maka semakin tinggi dan tajam daya cipta yang menghasilkan kreativitas. Kreativitas dan proses merupakan satu kesatuan, artinya proses tidak terjadi tanpa motivasi dan kreativitas, sehingga dapat dikatakan motivasi, kreativitas dan proses, merupakan sebuah persenyawaan, yang tanpa salah satunya, ibarat sebuah lingkaran setan, terjadi dengan saling mendukung.

Kreativitas sangat tergantung pada bagaimana seseorang memanfaatkan potensi dirinya, baik yang dibawa sejak lahir dengan bakat yang dimilikinya, ataupun lahir karena proses pembelajaran, latihan, pengembangan dan pengalaman. Setiap orang memiliki jalan yang berbeda dalam mengembangkan kreativitasnya, tergantung 
kesungguhan atau ketekunan sesorang untuk menjalani proses pembelajaran, latihan, pengembangan dan penggunakan pengalaman. Menurut seorang ahli" Bahaya terbesar pada situasi turbulasi, bukanlah pada turbulasi itu sendiri, akan tetapi pada perilaku yang masih menggunakan pola pikir masa lalu. ${ }^{27}$ Maknanya bahwa pada situasi turbulasi ( perubahan besar), katakanlah seperti era globalisasi, pengaruh perubahan besar-besaran, melingkupi IPOLEKSOSBUHANKAMNSA, gaya hidup sangat cepat dibanding dengan gaya hidup lama, kemajuan alat komunikasi dengan berbagai bentuk HP, menempuh seluruh wilayah tanpa terkecuali. Perubahan tersebut mempunyai pengaruh sangat besar, serta bisa mengancam kehidupan di bumi, kalau perilaku manusianya tidak ikut berubah, tetapi jika sikap dan perilaku manusia mampu mengimbangi perubahan tersebut, nyesuaikan diri, maka akan mendatangkan manfaat sangat besar juga. Dalam mengimbangi perubahan itu, peran pendidikan sangat signifikan, dengan metode yang tepat, dapat membangkitkan motivasi dan kreativitas peserta didik sebagai generasi pelanjut.

Era globalisasi dapat dikatakan, membuka peluang untuk berkreativitas, didukung motivasi untuk bangkit memperbaiki tingkat kehidupan. Untuk membangkitkan motivasi dan kreativitas dibutuhkan metode yang tepat, dipandang analisa yang dilakukan, berdasar pendapat ahli di atas, serta karaktristik metode active learning memeliki kelebihan -kelebihan, diyakini memberikan berpengaruh terhadap peningkatan motivasi maupun kreativitas peserta didik dengan talenta yang berbeda. Talenta peserta didik pasti terjadi perbedaan diantaranya, ada kreatif di bidang seni pahat, yang lainnya seni suara, seni lukis, penulisan syair atau prosa, sajak atau bahkan di dalam bisnis. Kreativitas selain bakat juga hasil pembinaan pendidikan, pelatihan atau pengalaman hidup seseorang. Itulah sebabnya dianalogikan bahwa kreativitas tergantung pada motivasi sesorang, pengalaman dan kemampuan masingmasing.

Era global, eranya seseorang menunjukkan kehebatannya untuk berkreativitas, dengan daya dukung teknologi yang serba digital, dan teknologi informasi yang membantu kemudahan dalam mencari informasi satau entitas yang

\footnotetext{
27 . Peter Druker ( 2003) dalam Endang Wirjatmi Trilestari, Systems Thinking, Penerbit. Dirjen Kesbang Depdagri,
}

Tahun $2008: 9$. 
sedang dikembangkan masyarakat di belahan dunia lain, wilayah lain, dengan motivasi dan keretaivitas yang tinggi, dapat dikombinasikan menjadi entitas terbarukan. Demikian peluang yang tebuka lebar, harus diimbangi dengan pengembangan pendidikan dan metode yang bekualitas, metode yang lagi tren di globalisasi ini adalah metode active learning. Melalui metode active learning, dapat menjadi pengungkit motivasi dan kreativitas, agar menghasilkan prestasi terbaik.

\section{Pengaruh Metode Active Learning Terhadap Peningkatan Motivasi dan Kreativitas Belajar Peserta Didik Di Era Globalisasi}

Lahirnya globalisasi memberikan gambaran pemikiran dunia terasa semakin sempit, terjadinya pertukaran informasi sangat cepat, transportasi menggunakan waktu singkat, semakin lama semakin hubungan yang saling terkait diberbagai bidang ekonomi, terbukanya MEA ( masyarakat ekonomi ASEAN ), pertukaran nilai-nilai budaya, tidak mempunyai batas, karena komunikasi Internasional lewat jalur Internet dan Politik internasional bebas aktif.

Fenomena perubahan tersebut langsung atau tidak langsung menuntut berpengaruh terhadap perubahan penyelenggaraan pendidikan. Pengaruh teknologi, sekarang tidak perlu menggunakan whait board sudah tergantikan oleh LCD, perkembangan jaringan teknologi informasi, terbukanya perpustakaan elektronik, perpustaan online, hal ini membuka kesempatan luas untuk mencari referensi, lain lagi bantuan geogle.com, yahoo.com dan banyak lagi yang tidak bisa disebutkan. Seseorang yang memiliki kretaivitas tinggi menciptakan aplikasi pasar onlie, menggunakan kemajuan teknologi informasi sebagai peluang, jual beli tidak harus kepasar tradisional, cukup melalui toko online, pesan tiket pesawat, kreta api, hotel cukup dengan online. Hal ini terbukti pendapat Endang Wirjatmi Trilestari, Systems Thinking,di atas, perubahan itu bagaimanapun hebatnya, tidak membahayakan, asalkan sikap dan perilaku manusianya ikut berubah.

Di sisi lain pengaruh mengandung dua sisi, selain positif penaruh negative pasti ada, dengan berbagai macam bentuk, yang tidak mungkin ditolak. Untuk menangkal semua masalah tersebut, hanya dengan menyiapkan moral positif peserta didik, melalui pendidikan, sebagaimana dikemukakan Endang Wirjatmi Trilestari, Systems Thinking "Perubahan tersebut sesungguhnya tidak berbahaya jika dapat 
disikapi dengan baik. ${ }^{28}$

Moral yaitu baik buruk yang diterima umum mengenai perbuatan, sikap, akhlak, budi pekerti. Sesungguknya menyiapkan moral itulah yang menjadi tujuan pendidikan nasional. UU No. 20 Tahun 2013, Tentang Sistem Pendidikan Nasional ( Pasal 1) menyebutkan, Pendidikan adalah usaha sadar dan terencana untuk mewujudkan suasana belajar dan proses pembelajaran agar peserta didik secara aktif mengemangkan potensi dirinya untuk memiliki kekuatan spiritual keagamaan, pengendalian diri, kepribadian, kecerdasan, akhlak mulia, serta ketrampilan yang diperlukan dirinya , masyarakat, bangsa dan Negara. ${ }^{29}$

Mewujudkan tujuan itu, butuh perjuangan melalui proses yang terencana dan terus menerus, dan para ahli berperan menciptakan metode-metode yang dapat mendukung terciptanya tujuan tersebut. Dan metode yang paling baik saat ini adalah metode active learning, metode ini berfokus pada pengembangan potensi, partisipasi, motivasi dan kreativitas peserta didik. Peserta didik menurut UU No, 20 Tahun 2013, adalah anggota masyarakat yang berusaha mengembangkan potensi diri melalui proses pembelajaran, yang tersedia pada jalur, jenjang, dan dan jenis pendidikan tertentu. ${ }^{30}$

Uraian dan definisi di atas, fenomena globalisasi pasti memberikan pengaruh terhadap kehidupan bermasyarakat dan penyelenggaraan pendidikan. Pengaruh globalisasi itu dapat berbentuk positif dan negatif. Motivasi mengandung nilai moral sehingga merupakan jiwa, dan alat penggerak dari kehidupan seseorang, orang yang ingin kehidupan memiliki nilai maka harus memotivasi dirinya. Ibarat selembar mata uang kertas biasa, sekeping mata uang logam, dia memiliki nilai tertentu, memiliki harga tersendiri, masalah besar apa kecil, tergantung orang yang membuat nilai, karena itu dia memiliki kemampuan tersendiri dalam pemanfaatannya. Begitu juga halnya manusia, ia lah yang membuat nilai bagi dirinya sendiri, walaupun tidak sesederhana seperi itu, manusia memiliki akal, pikiran kemauan serta kemampuan, jadi yang menentukan nilai kemampuan untuk menghadapi masalah adalah manusia itu sendiri, ia mampu memotivasi dan berbuat kreatif terhadap diri

28 . Endang Wirjatmi Trilestari, Systems Thinking, Ibit, tahun2008:9.

${ }^{29}$. Eka Prihatin, Dr.,M.Pd., Manajeme Peserta Didik, Penerbit. Alfabeta, Bandung, tahun 2014:5.

30. Eka Prihatin, ibid : 3. 
dan lingkungannya.

Pendidikan sangat berpengaruh terhadap peningkatan motivasi dan kreativitas peserta didik, jika ia mampu menempa kemampuan, kemandirian dirinya, responsif terhadap lingkungan sosial, selama mengikuti proses pembelajaran. Oleh sebab itu perhatian terhadap metode sangat perlu, dapat meningkatkan keaktifan belajar, menentukan kualitas perilaku peserta didik didalam belajar. Secara logika naluri manusia itu, pasti berkeinginan melanjutkan kehidupannya, dalam kondisi dan situasi apapun, ia harus memotivasi dirinya mencari ilmu pengetahuan, menempa keterampilan, mencari pengalaman sebanyak-banyaknya, agar menjadi manusia berkemapuan menciptakan, harapan-harapan yang dibutuhkan.

Keaktipan belajar menurut Nanan Sudjana dan Bonwell, metode active learning memiliki karakteristik yang signifikat dengan teori motivasi menurut Maslow. Maslow memberikan kreteria kebutuhan manusia menjadi lima tingkat kebutuhan, namun dalam kaitannnya dengan penelitian ini, dikombinasikan secara spesifik sesuai konteks metode pembelajaran, antara lain diikutkan berpastisipasi dalam proses belajar, diberikan kesempatan memberikan ide-ide, memberikan saran-saran untuk memperlancar proses pembelajaran, sehingga peserta didik merasa dihargai dan itu memang menjadi roh metode active learning.

Pendapat ke tiga ahli tersebut, dapat meningkatkan motivasi dan kreativitas peserta didik, masih dalam proses berjuang dalam pembentukan watak, kemampuan, pengetahuan serta keterampilan. Peserta didik tergolong generasi pelanjut, harus mendapat pembinaan, agar memiliki kualitas dan kompetensi, bisa bermanfaat bagi keluarga, masyarakat, bangsa dan Negara.

\section{SIMPULAN}

Perubahan adalah sebuah keniscayaan dalam kehidupan manusia di dunia yang fana ini,tidak ada yang tidak berubah, kecuali Sang Pencipta yang Maha Kuasa. Menghadapi perubahan tentu harus mempersiapkan diri, dengan berbagai upaya, banyak ikhtiar dapat dilakukan, melalui pendidikan, pembelajaran keterampilan, pengalaman. Upaya yang paling tepat pada peserta didik yang masih usia belajar, bahkan yang tidak usia sekolahpun dapat belajar melalui paket A dan lainnya. Hal ini menunjukkan demikian penting pendidikan dan proses belajar mengajar. Sudah 
banyak model pembelajaran yang diterapkan dalam penyelenggaraan pendidikan di Indonesia, dan dengan berbagai motede belajar mengajar, sampai sekarang dan secara berkesinambungan.

Metode yang sekarang diunggulkan adalah active learning, metode yang berfokus pada peserta didik, metode ini digunakan dengan keyakinan dapat memacu belajar mandiri, belajar aktif, partisipatif, dapat mengolah potensi ilmiah mereka untuk mendalami materi dan mencari solusi memecahkan masalah selama proses pemebelajaran berlangsung. Pembelajaran dengan metode ini harus didukung oleh lingkungan yang kondusip, aman, tentram, nyaman dan menyenangkan, baik dari lingkungan sekolah maupun diluar sekolah. Dilingkungan luar sekolah sekarang ini peran serta wali murid juga digerakkan dengan metode partisipatif melalui pembentukan BP.3.

Metode active learning menurut hasil pembahasan di atas dapat berpengaruh terhadap peningkatan motivasi dan kreativitas peserta didik di era globalisasi. Kreativitas tanpa motivasi akan berjalan timpang, keduanya akan berjalan dengan normal, jika ditempuh melali pendidikan yang berkualitas. Pendidikan salah satu upaya pembekalan diri, menjalani kehidupan dengan berbagai perubahan yang terjadi, sejak Nabi Adam AS, zaman purba dan sekarang ini zaman globalisasi. Globalisasi dengan kemajuan teknologi informasi, demikian pesat, dapat membantu mempermudah segala macam pekerjaan, mempermudah segala urusan dengan sistem komputerisasi, digital, berbagai macam sarana komunikasi dengan bantuan internet. Komunikasi membuat jarak terasa sempit, jarak semakin dekat, model manual digantikan degan sistem digital, diberbagai macam pekerjaan, kantoran maupun untuk berwirausaha.

Menghadapi pesatnya perubahan pola hidup masyarakat, diperlukan motivasi dan kreativitas yang tinggi. Orang yang memiliki motivasi ia akan melahirkan ide-ide, dan berbagai macam tata cara menempuh kehidupan yang serba canggih. Seseorang yang memiliki motivasi tinggi, akan mendorong terciptanya kreativitas yang dapat mewujutkan inovasi, menyesuaikan kearah yang serba kebaruan dalam perkembangan hidup sekarang ini. Pendidikan dengan metode active learning, sangat sesuai dengan perkembangan zaman, dan dapat berpengaruh terhadap peningkatan motivasi dan kreativitas belajar peserta didik di era globalisasi. 


\section{DATAR PUSTAKA}

Achmad Muslih, Skripsi, Pengaruh Lingkungan Belajar, Kebiasaan Belajar Dan Motivasi Belajar Terhadap Hasil Belajar, Fakultas Teknik Universitas Negeri Yogyakarta, Tahun 2014:14.

Ali Muhtadi, Model Pembelajaran "Active Learning" dengan Metode Kelompok untuk Meningkatkan Kualitas Proses Pembelajaran di Perguruan Tinggi, 2019: 4 .

Conny R. Semiawan, Prof.DR, dkk, Dimensi Kreatif Dalam Filsafat Ilmu, penerbit PT. Remaja Rosdakarya,Bandung, tahun 1999:61

Dadang Suhardi, dkk, Manajemen Pendidikan, penerbit Alfabeta, Bandung, tahun 2012: 205.

Departemen Pendidikan dan Kebudayaan, KBBI, Penerbit Balai Pustaka, Jakarta , tahun 1990:593.

Eka Prihatin, Dr.,M.Pd., Manajeme Peserta Didik, Penerbit. Alfabeta, Bandung, tahun 2014:5.

Miftah Thoha, Perilaku Organisasi, Penerbit PT Raja Grafindo Persada, Jakarta, tahun 1999:206.

Michael A.West, Mengembangkan Kreativitas Dalam Organisasi, Penerbit Kanisius, Yogyakarta, tahun 2000:14.

Mukhlison Effendi, Integrasi Pembelajaran Active Learning dan Internet-Based Learning dalam Meningkatkan Keaktifan dan Kreativitas Belajar, Nadwa | Jurnal Pendidikan Islam Vol. 7, Nomor 2, Oktober 2013: 288.

Nur Asiah, menurut Uno, Analisis Kemampuan Praktik Strategi Pembelajaran Aktif (Active Learning) Mahasiswa Pgmi Fakultas Tarbiyah Dan Keguruan Iain Raden Intan Lampung, Terampil: Jurnal Pendidikan dan Pembelajaran Dasar Volume 4 Nomor 1 Juni 2017 : 22.

Nur Latifah, Pendidikan Islam di Era Globalisasi, Palapa: Jurnal Studi Keislaman dan Ilmu Pendidikan Volume 5, Nomor 1, Mei 2017: 202.

Robert L. Mathis dan John H.Jackson, Manajemen Sumber Daya Manusia, Salemba Empat, Jakarta,2002: 91.

Sudarsono ( 2003) dalam Endang Wirjatmi Trilestari, Systems Thinking, Penerbit. Dirjen Kesbang Depdagri, tahun2008 :9.

S.P.Siagian, MPA, Dr, Filsafat Adminstrsi, Penerbit PT Gunung Agung, Jakarta, tahun 1980:129.

Triguno, DIPL EC.,LLL, Drs.Budaya Kerja, Diterbitkan PT Golden Trayon Press, Jakarta tahun 2003:125.

Zaini, Skripsi dengan judul :Implementasi Metode Active Learning Dalam Pembelajaran Pendidikan Agama Islam Kelas V Di Sd Islam Al-Azhar 28 Solobaru, tahun $2018: 8$

Alfred North Whiteheadhttps://id.wikipedia.org/wiki/Kreativitas(Filsafat Proses)( Diakses 17 Mei 2019) 
Polio ( 1984 ), https://media154.wordpress.com/artikel-internet-desain-dan-web3/strategi-pembelajaran-active-learning/

McKeachie (1986), https://media154.wordpress.com/artikel-internet-desain-danweb-3/strategi-pembelajaran-active-learning/

Silberman (2009:xxii), https://media154.wordpress.com/artikel-internet-desain-danweb-3/strategi- pembelajaran-active-learning/

Anthony Giddens, Globalisasi, https://id.wikipedia.org/wiki/Globalisasi 